\title{
Erratum
}

\section{Expression of mouse Tla region class I genes in tissues enriched for $\gamma \delta$ cells}

\author{
Pirooz Eghtesady, Kurt A. Brorson, Hilde Cheroutre, Robert E. Tigelaar, Leroy Hood, \\ and Mitchell Kronenberg
}

Immunogenetics 36: 377-388, 1992

The following references were missing from the abovementioned article:

Stanton, T. and Boyse, E.: A new serologically defined locus, Qa-1, in the Tla region of the mouse. Immunogenetics 3: 525-532, 1976

Steinmetz, M., Winoto, A., Minard K., and Hood L.: Clusters of genes encoding mouse transplantation antigens. Cell 28: $489-492,1982$

Strominger, J.: The $\gamma \delta$ T-cell receptor and class Ib major histocompatibility molecules of immune recognition. Cell 57: 895-898, 1989

Stroynowski, I., Soloski, M., Low M., and Hood, L.: A single gene encodes soluble and membrane-bound forms of the major histocompatibility Qa-2 antigen: anchoring of the product by a phospholipid tail. Cell 50: 759-768, 1987

Stroynowski, I.: Molecules related to class-I major histocompatibility complex antigens. Annu Rev Immunol 8: 501-530, 1990

Transy, C., Nash, S. R., David-Watine, B., Cochet, M., Hunt, S. W. III, Hood, L. E., and Kourilsky, P.: A low polymorphic mouse $H-2$ class I gene from the Tla complex is expressed in a broad variety of cell types. J Exp Med 166: 341-361, 1987
Vidovic, D., Roglic, M., McKune, K., Guerder, S., MacKay, C., and Dembic, Z.: $Q a-1$ restricted recognition of foreign antigen by a $\gamma \delta$ T-cell hybridoma. Nature 340: 646-650, 1989

Weiss, E., Golden, L., Fahrner, K., Mellor, A., Devlin, J., Bullman, H., Tiddens, H., Bud, H., and Flavell, R.: Organization and evolution of the class I gene family in the major histocompatibility complex of the C57BL/10 mouse. Nature 310: 650-655, 1984

Widmark, E., Ronne, H., Hammerling, U., Servenius, B., Larhammar, D., Gustafsson, K., Bohme, J., Peterson, P., and Rask, L.: Family relationships of murine major histocompatibility complex class I genes. Sequence of the $T 2 A^{a}$ pseudogene, a member of gene family 3. I Biol Chem 263: 7055-7059, 1988

Wolf, P. R. and Cook, R. G.: The $T L$ region gene 37 encodes a Qa-1 antigen. J Exp Med 172: 1795-1804, 1990

Wu M., Van Kaer, L., Itohara, S., and Tonegawa, S.: Highly restricted expression of the Thymus Leukemia antigens on intestinal epithelial cells. $J$ Exp Med 174: 213-218, 1991

Wysocki, W. L. and Sato, V. L.: Panning for lymphocytes: A method for cell selection. Proc Natl Acad Sci USA 75: 2844-2848, 1978

Yasumura, Y., Tashijian, A., and Sato, G.: Establishment of four functional, clonal strains of animal cells in culture. Science 154: $1186-1189,1966$ 